\title{
Namık Kemal ve 'Vâveylâ' Şiiri Üzerine Notlar
}

Öz

Kadri NAZLI*

Namık Kemal, Türk edebiyat tarihi içerisinde nevi şahsına münhasır bir kişiliktir. Kaleme aldığı eserleri ile pek çok alanda öncü olmuş, halefi pek çok sanatçıyı etkilemeyi başarmıştır. Türk edebiyatına hem şekil hem de muhteva yönünden pek çok yenilik kazandırmıştı. Tanzimat birinci kuşak şairleri içerisinde ortaya çıkmış ve etkisini günümüzde dahi sürdürebilmiştir. Ortaya çıktı̆ı devrin çalkantıları içerisinden kendine has özelliklerle sıyrılmıştır. 'Eskiyeni', 'Doğu-Bat', 'alaturka-alafranga' tartş̧maları içerisinde yeteneği ve üslubuyla farklılaşmıştı. Öne sürdüğü 'hürriyet ve vatan' kavramları ile 'vatan ve hürriyet şairi' olarak anılagelmiştir. Şairin üslubunun en belirgin özellikleri olan 'coşkunluk ve heyecan' duyguları şiirlerinde başat roldedir. Bu duyguların ışığında yazıımış 'Vâveylâ' Namık Kemal'in 'vatan' kavramını büyük bir coşkuyla haykırdığı şiirlerinden biridir. Bu çalışmada Kemal'in şahsi hayatı ve yaşadığı devir hem siyasi hem de edebi anlamda ele alınacak ve 'Vâveylâ' şiiri bu bilgiler ışığında tahlil edilmeye çalışılacaktır.

Anahtar Kelimeler: Vâveylâ, Namık Kemal, hürriyet, vatan, Tanzimat şiiri.

\section{Notes on Namık Kemal and His Poem 'Vâveylâ'}

\begin{abstract}
Namık Kemal, is a unique character in Turkish Literature History. He became pioneer in many aspects with his various works and effected many successors artists. He brought in many innovations both in terms of content and form to the Turkish Literature. He came out among the first generation of Tanzimat poets and could continue to impact even today. He stripped himself from the turmoil of the period he was in by his own characteristic features. He differed by his talent and style from the 'Old-New', 'East-West', 'Ottoman-European' discussions. He has been known as 'patriotism and liberty poet' because of being the creator of Turkish forms of the terms 'patriotism and liberty'. 'Enthusiasm and excitement' are in the dominant role in his poetry as a part of his most significant style feature. Written in the light of these feelings, 'Vâveylâ' is one of Namık Kemal's poems in which he cries out the notion of 'patriotism' with eager. In this study, Kemal's personal life and the period he lived will be discussed in terms of both political and literary and his poem 'Vâveylâ' will be analyzed in the light of these information.
\end{abstract}

Keywords: Vâveylâ, Namık Kemal, liberty, homeland, Tanzimat poetry.

* Türk Dili ve Edebiyat Doktora Öğrencisi, Dicle Üniversitesi Yabancı Diller Yüksekokulu, knazli@dicle.edu.tr 


\section{GiRiş}

Türk edebiyatının Batı ile imtihanının geçmişi bir asırdan fazla bir zaman sürmüştür. 18. yüzyıl sonlarında çökme emareleri gösteren devlet yapısını ayakta tutma amaçlı askeri sahada başlayan ıslahatlar 19. yüzyılda Tanzimat Fermanı ile resmi bir hüviyet kazanmıştır. Alt asır boyunca hüküm sürmüş bir imparatorluk, zamanında tebaası konumunda olan Bat'nın üstünlüğünü kabul edip yüzünü ve dahi tüm bedenini Batı'ya yöneltmiştir. Bu yöneliş hayatın her alanına olduğu gibi edebiyat sahasına da yansımıştır. 'Muasır medeniyet' olarak kabul gören Batı aracılığıyla Türk edebiyatına pek çok kavram, fikir ve 'yenilik' girmiştir. Yalnız toplumsal bir hazır olamama durumundan dolayı çok uzun bir süre (yaklaşık yüz yıl) Batlılaşma hareketi bir sorunsal olarak işlenmiştir (Moran, 2009: 24). Nitekim bu sorunsal Tanzimat'ın ilk kuşağında ve onu takip eden Servet-i Fünun kuşağında şiddetli birçok tartş̧manın vuku bulmasına sebep olmuştur. Eski-yeni, alaturka-alafranga, Doğu-Batı ve buna benzer kavramlar etrafinda dönemin aydınları, devlet adamları ve fikrî zümreye ait kimseler arasında tartışmalar ve mücadeleler yaşanmıştır. 'Yeni' olan her şeyin her daim karşısında mücadele etmesini gerektirecek bir 'eski' var olagelmiştir ki bu dönem için de durum bu şekilde olmuştur.

Tanzimat ile birlikte oluşan edebiyat içerisinde 'eski-yeni' ve Batlılaşma ile ilgili örneklere sıkça rastlamak mümkündür. Bu noktada ortaya bir zarf-mazruf problemi de açığa çıkmıştır. Şöyle ki, Doğulu değerler ve geleneklerle yetişmiş olan (mazruf) kalemlerin üzerine giydirilen Batilı fikriyat (zarf) bir doku uyuşmazlı̆ıına sebep olmuştur. Bu uyuşmazlık da edebi eserlerde kendini birbiri ile çelişen düşünce ve duygularla açığa vurmuştur. Diğer bir deyişle bir çeşit düalizm anlayışının doğmasını sağlamıştır. Bu durumun en açık örneği Namık Kemal'in 'Hürriyet Kasidesi' adlı şiiri olduğu söylenebilir. Zira Kemal, eski (kaside) ile yeniyi (hürriyet) şiirine başlık olarak seçerek ikilik örneğini eserine taşımıştır.

Tanzimat kuşağının en önemli kalemlerinden biri Namık Kemal'dir. Tüm edebiyat kaynaklarında yeniliğin öncüsünün Şinasi olduğu söylenir ki Namık Kemal'in kendisi de Abdülhak Hamid ve Şinasi arasında 'hatt-ı ittisal' olduğunu belirtir. Ama Ahmet Hamdi Tanpınar bu konuda ne Kemal ne de diğer kaynaklar gibi düşünür. Ona göre Şinasi olsa olsa bir hareket noktasıdır ve aslında gerçek manada yenilik Kemal ile başlar (Tanpınar, 1992: 212). Türk Edebiyatına 'vatan, millet, istiklal' kavramlarını sokan ve bunları bir sistem halinde ifade eden ilk düşünürümüzdür (Dizdaroğlu, 1995: 16). Nitekim Mehmet Kaplan, Namık Kemal'in eserleri ile Türkiye'de tesiri uzun yıllar sürecek bir 'hürriyet miti' ve 'hürriyet kahramanı' yarattğını belirtmektedir (Kaplan, 1991: 179). Tanpınar, Kemal'in hayatımıza sokmuş olduğu 'hürriyet' kavramı meselesini bir üst noktaya taşır ve Kemal'in başka hiçbir meziyeti olmasa dahi hayatımıza sokmuş olduğu bu kavramın bile tek başına onu tarihimizin en büyük ve en istisnai hadiselerinden biri yapmaya yeterli olduğunu düşünür (Tanpınar, 1992: 212). Buna ilaveten "hiçbir kimsenin tesiri, edebiyatımızda gerek cemiyetimizde Namık Kemal'inki kadar olmamıştı" der (Tanpınar, 2002: 176). Bu incelemenin konusu 'vatan ve hürriyet' şairi olarak nam salmış Namık Kemal'in önemli şiirlerinden biri olan 'Vâveylâ' şiiri olacaktır. Bu şiirin incelemeye tabi tutulmasının iki temel amacı vardır; vatan şairi olarak anılan Namık Kemal'in bu namı edinmesini sağlayan özelliklerin gösterilmesi ve 'Hürriyet Kasidesi' kadar olmasa da en önemli şiirlerinden biri olmasına rağmen şiir üzerine yapılmış detaylı bir çalışmanın olmamasıdır. Şiir tahlil kitaplarında üzerinde kısaca durulun yorumların dışında kayda değer bir incelemeye rastlanmamaktadır. 
Bir milletin, toplumun ya da devletin tarihinin anlaşılabilmesi için edebi eserlerden yararlanıldığı gibi edebi eserlerin tam manasıyla anlaşılabilmesi için yazıldığı dönemin incelenmesi elzemdir. Devrin yanında eser sahibinin hayatının da en az devir derecesinde önem arz ettiğini Mehmet Kaplan şöyle ifade eder: "bir devri en iyi ifade eden şahsiyet, bize o devrin anahtarını verebilir" (Kaplan, 2015: 12). Edebi eser incelemelerinde elde edeceğimiz bu 'anahtar' aracılığı ile tarihin ve edebiyatın kilit altında kalmış tüm gizemli kapıları ardına dek açabilme imkânı edinmiş olacağız.

Kaplan, edebi eserlerin bir bütün olduğunu ve bu bütünü oluşturan parçaların eser ile birlikte müellifin ferdî hayatının ve devrin özelliklerinin birbirine eklemlenmiş olduğunu belirtir. Diğer bir ifadeyle müellifin eserini ortaya çıkarmak için kullanmış olduğu konu, fikir, kelime, hayal ve ahenk gibi unsurlar ve diğer her şey bize hem onun şahsiyetini ifşa eder hem de devri gösterir (Kaplan, 2015: 12).

Mehmet Kaplan'ın edebi eser incelemeleri için işaret ettiği ve bu çalışma içinde izlenecek yöntem şemasının şu şekilde özetlenmesi mümkün olacaktır.

- Devir (eserin yazıldığı devrin özellikleri/şartları)

- Şahsiyet (müellifin şahsi hayat)

- Eser

Bu şema ışığında konumuza geçmeden evvel özelde 'Vâveylâ' şiirinin tahlili adına genelde tüm eser tahlilleri adına Kaplan'ın eser tahlil bahsine dair düştüğü şu şerhi hatırlatmak yararlı olacaktır:

"tahlillerle herkesin tarafindan kabul edilmesi gereken kati neticelere ulaştı̆ımızı iddia etmek gülünç olur. Valery "edebi eserin değeri, her şahsa göre ayrı bir tefsire meydan vermesindedir" der" (Kaplan, 2015: 13).

\section{TANZIMAT: DÜALIZMIN ALTIN ÇAĞLARI YA DA YENI BIR DÖNEMIN DOĞUM}

\section{SANCILARI}

\subsection{Siyasî Arka Plan}

Toplumların kültürel gelişimi ve değişimi hiçbir devir ve dönemde siyasi vakalardan bağımsız bir şekilde cereyan etmemiştir. Her dönüşüm mutlaka devrin arka planında meydana gelmiş pek çok hadisenin getirdiği bir bagaj barındırmaktadır. Bu bagajın ne ile doldurulduğu dönemin karanlıkta kalan yanlarına ışık tutması, yol gösterici bir mahiyet taşıması bakımından oldukça önemlidir.

Bu minvalde 1839 yılında ilan edilen Tanzimat Fermanı'nı hazırlayan arka planın bilinmesi icap eder. Bu çalışmada yer verilecek olan noktaların amacı dönemin edebi koşullarını oluşturan tarihi ve siyasi gelişimleri hakkında kısa bilgiler vermek olacaktır.

Osmanlı́nın Bat ile olan ilişkisinin tarihi bir geçmişi Tanzimat'a gelinceye kadar çeşitli seviyelerde ve dönemlerde hep var olagelmiştir. Önceki yüzyıllarda daha düşük düzeyde gözlemlenebilecek bu gelişimler 18.yüzyılda askeri alanda (Nizam-ı Cedit) kendini apaçık bir şekilde göstermiştir. Bu değişim yoğunluğunun askeri alanda ortaya çıkması zaten savaş ve asker kültürüne aşina bir toplum olması hasebiyle Osmanlı coğrafyasında sindirilme sürecinin kısmen rahat geçmesini sağlamıştır. Bu geçiş sancılarının arttı̆̆ asıl nokta Tanzimat'ın getirdikleri olmuştur. Tanzimat'la birlikte öğretim laikleşir, hukuk birleştirilir, kapitalist Batı finans sistemi örnek alınarak tüm finans sistemi değiştirilir, 
Avrupai yaşam biçimi teşvik edilir. Bu dönemi takiben Abdülmecid döneminde (18391861) kanun önünde herkesin eşitliği kabul edilir, finans sistemi modernleştirilir, idare ve hukuk sisteminde yenilenmeye gidilir, ordu yenilenir, büyük okullar açılır, siyahların köleliği kaldırılır(Roux, 2015: 440-441).

18.yüzyılda askeri alanda başlayan modernleşme hareketini yüzyılın sonunda Avrupa model alınarak siyasal, kültürel ve idari değişmeler takip etmişti. 19.yüzyılı da içine alan ve özellikle III. Selim ve II. Mahmut tarafindan yürütülen ıslahat hareketleri Osmanlı toplumunu kültürel bir çelişkiler yumağı içerisine itmiştir (Karpat, 2012: 14-15). Askeri alandaki ıslahatların ardından yapılan idari ıslahatlar yeni bir yönetim modelinin ortaya çıkmasına sebep olmuştur; yeni merkeziyetçilik. Geleneksel Osmanlı idari yapısı padişahın son karar mercii olduğu dar ve sınırlı bir yapıya sahip bir sistemden oluşurken, oluşan bu yeni yapıda ise idari sınıfin yetkilerine ortak olan bir yeni yapı; memurlardan oluşan bürokratik bir yapı ortaya çıkmıştır (Karpat, 2012: 16-18).

Osmanlı devletinin 18. ve 19.yüzyıl siyasi yapısında ortaya çıkıp güçlenen bürokratik sınıfin devrin hem idari hem de toplumsal yapısına yansıyan etki alanı günümüze kadar var olagelmiştir. Günümüz siyasi hayatında da bahsi geçen 'bürokratik vesayet' kavramının köklerinin bu dönemlerde filizlendiği söylenebilir.

Osmanlı devlet sistemine yeni dâhil olan bu sınıf aslında yüzyıllardır var olagelen idari yapıdaki kamplaşmalar içerisinde sadece yeni bir cephe oluşturmuştur. Berna Moran, bu kamplardan geçmişi daha köklü olanlara, devletin yapısını oluşturan padişah ve Enderun mektebinde yetişip asıl amacı padişaha hizmet olan onun dar çevresi ile medreselerde eğitim görüp ulema sınıfinı oluşturanların oluşturduğu çevre şeklinde işaret etmektedir (Moran, 2009: 12). Bu iki sınıf farklı kültür çevrelerinde yetişmiş ama halktan kopuk olma noktasında ortaklaşan iki ayrı zümredir.

Şerif Mardin avam ve havas olarak tanımlanabilecek bu ayrım için "küçük kültür", "büyük kültür" kavramlarını kullanmaktadır. Moran, iki sınıf, iki kültürü bir arada tutan unsurun köklü bir ideoloji, yani İslam olduğunu belirtmektedir (Moran, 2009: 13). İki sınıfi yani yönetici ve yönetilen sınıf bir arada tutan unsurlar ıslahatlarla beraber çatırdama emareleri göstermeye başlamışt. Devleti ayakta tutmak için yapılan her yenileşme hareketi beraberinde farklı sıkıntıların ortaya çıkması ile sonuçlanmaktaydı. Askeri alandaki ıslahatlar, askerin ayaklanmasına, idari yapıdaki ıslahatlar nüfuzunu kaybetmek istemeyen ayan sınıfinın itirazlarına sebep olmuştu. Islahatların halktaki yansıması ise devletin Batıdan ithal ettiği yeniliklere mesafeli durması ve bu mesafenin de var olan kopukluğun artması olmuştur.

Bu kopukluklara edebiyat sahasında da rastlamak mümkündü. Divan edebiyat ve halk edebiyatı olarak ayrılmış iki saha farklı kollardan ve sınıflardan muhataplarıyla yüzyıllardan beri ayrı dünyalara hitap etmekteydiler. Ama bu ayrışma içerisinde bile Moran'ın da belirttiği üzere Leyla ile Mecnun, Yusuf ile Züleyha, Ferhad ile Şirin gibi konuları bakımından ortaklaşan unsurlar bulunabilmekteydi ve bu durum topyekûn bir yabancılaşmayı engelliyordu. 19.yüzyıl ile birlikte kopuklukların hem siyasi hem edebi anlamda artmasına sebep olan yeni bir girişim denendi. Bu girişim yöneticiler tarafindan mevcut durumu iyileştirme adına yapılan Batılılaşma hareketidir. Islahatlar ile başlayan Batılılaşma hareketi, 1839'daki Gülhane Hatt-ı Hümayunu ile resmi bir hüviyet kazanarak Tanzimat döneminde başlamıştır (Moran, 2009: 14). 
Tanzimat ile birlikte gelen yeniliklere karşı halkın tepkisi önceki dönemlerde olduğu gibi mesafeli olmamıştır. Bunun en önemli sebebi Ruslarla gerçekleşen Kırım Savaşı ve sonucunda 1856 yılında imzalanan Paris Antlaşması'dır. Avrupalı devletlerin Ruslara karşı Osmanlı Devleti'nin yanında yer alması Avrupa'ya duyulan kuşkuları azaltmakla kalmamış Avrupai yaşam tarzı, dil ve kültüre ilgiyi de arttrmıştır (Karpat, 2012: 52). Nitekim dil, kültür ve yaşantıya olan bu özenme hali Tanzimat edebiyat üzerinde de etkilerini göstermiştir. 18.yüzyılda başlayıp 19.yüzyılda Tazimat Fermanı ile resmileşen tüm bu ıslahat döneminin en büyük engeli zarf ile mazruf arasındaki uyumsuzluk olmuştur. Zarf Avrupai, mazruf ise Osmani bir ihtivaya sahip olduğundan yapılan ıslahatlara yönelik bir doku uyuşmazlığından söz etmek mümkündür ki bu durumu "Nizam-ı Cedit" ordusu üzerinden örneklendirilebilir. Nizam-ı Cedit, III. Selim tarafindan kurulmuş bir ordudur. Bu ordu Fransız üniforması giyip Fransız subaylar tarafindan eğitilmekteydi. Bu durum sembolik anlamda yüzünü Batı'ya çevirmenin yanı sıra Bat medeniyetinin Osmanlıİslam medeniyetinden üstünlüğünü zımnen kabul etmek demektir (Karpat, 2012: 20).

\subsection{Edebî Arka Plan}

Önceki bölümde kısaca değindiğimiz Osmanlının son dönemindeki siyasi çalkantılar bir asırdan daha uzun sürmüştür. Siyasi alanda yaşanan çatışmalar karşılıklı kutupların oluşmasına ve bu kutuplarında Doğu-Bat, eski-yeni, alaturka-alafranga gibi pek çok ikili kavramın mücadelesinin yaşanmasına neden olmuştur. Bu siyasi mücadele pek tabiidir ki kendini en belirgin olarak edebiyat alanında hissettirmiştir.

Edebî anlamdaki Tanzimat'ı Ramazan Korkmaz şu şekilde tanımlamaktadır;

“... bir arayışlar, sorgulayışlar ve hep yeniden oluşlar dönemini içine alan bir süreçtir ki Şinasi'nin yenilik yolundaki ilk denemelerini yaptı̆ı 1859 yılında başlar ve kendilik değerini esas alarak dünya ile bütünleşmeyi amaçlayan Milli Edebiyat'a kadar; hatta uzun yıllar süren bu siyasal/ toplumsal ve edebî arayışların, kavramsal bir arketip olarak somutlaştı̆ı genç Türkiye Cumhuriyeti'ne kadar devam eder" (Korkmaz, 2007: 29).

Tanzimat'ın kelime anlamından mütevellit getirdiği yenilikler özellikle "yeni batılı fikirler ve bu fikirlere bağlı teklifler çerçevesinde muhtevadan başlayarak üslup, şekil ve teknikte" (Gariper, 2007: 41) devam etmiştir. Bu yenilik hareketinin öncüleri Şinasi, Namık Kemal, Ziya Paşa ve Ahmet Mithat Efendi olarak öne çıkmaktadırlar.

Eski kültür normları ile yetişmiş Tanzimat nesli yenilik arzularını her daim 'edep' içerisinde yapmaları dolayısıyla eserlerinde şekli bakımdan eskilerin izlerine sıkça rastlamak mümkündür. Bu dönem sanatçılarının yüzünün halka doğru olduğu ve edebiyatı ve sanat da toplumu eğitip aydınlatma amacı doğrultusunda bir araç olarak kullanmak gerekliliğine inanmaktadırlar. Bu amaç doğrultusunda halka ulaşmanın ilk adımı olarak halk dilinde söyleme ihtiyacı hâsıl olmuştur. Nitekim "dilin değişmesi gerektiğine inanan ibrahim Şinasi, halkın anlayacağı "safi Türkçe "ye dayanan bir yazı dili kurmak ve bu dille edebî eser ortaya koymak ister" (Gariper, 2007: 42). Şinasi'nin 'Şair Evlenmesi' ile başlatmış olduğu bu dilsel yaklaşım yine Şinasi tarafindan kurulan gazetelerin çıkması ile artı bir zaruret haline dönmüştür. Devrin şartları içerisinde topluma ulaşıp toplumu aydınlatma ya da topluma fikri propaganda yapabilmenin en etkili metodu gazete çıkarmak olmuştur. Gazetenin yanı sıra diğer bir kitle iletişim aracı da tiyatro olmuştur ki bu noktada bu 
çalışmaya konu olan şiirin de şairi Namık Kemal'in baskınlığı söz konusudur. Namık Kemal coşkunluğu, heyecanı ve hırsıyla bu dönemki edebî hareketin adeta sesi konumuna yerleşmiştir.

Ziya Paşa, bu dönemin en önemli isimlerindendir. Klasik üslubu devam ettiren bir tarza sahiptir. Dönemin ikili mücadelelerinin vücut bulmuş halidir denilebilir. 'Şiir ve İnşa' da eskiyi yererken 'Harabat Mukaddimesinde' ise eski edebiyattan övgü ile bahsetmiştir. Ziya Paşa bu yönüyle dönemin ikilik, kafa karışıkığı ya da düalizmin vücut bulmuş hali gibidir.

Tanzimat'ın bu ikilik meselesi Tanpınar'ın veciz ifadelerinde zuhur etmiştir;

"Bugün bile halk dilinde ve hatta fikir hayatında o zamanlardan kalan "alafranga" ve "alaturka" (musikide olduğu gibi) "eski" ve "yeni" (zihniyet meselelerinde) tabirleriyle ifade edilen bu ikilik realitesi Tanzimat'ın en büyük fatalitesidir" (Tanpınar, 2013: 144).

Eski ile bağını koparmadan yeniyi oluşturma çabalarının bir benzerini Ahmet Mithat'ın romanlarında da rastlamaktayız. Pertev Naili Boratav'ın ilk romanlarımızda meddahlık geleneğinin izlerini araştırırken Ahmet Mithat'ın eserlerinde nası bir meddah gibi davrandığına dikkat çekmektedir (Moran, 2009: 25). Bu durum eski geleneğin etkilerinin devamına dair önemli bir veri olarak karşımıza çıkmaktadır.

Tanzimat'la başlayıp sonraki süreçte de etkisini devam ettiren bu devrin en büyük sorunsalı Batılılaşma hareketidir. Neredeyse tanınmış tüm yazarların eserlerinde bu hareketin izlerini bulmak mümkündür (Moran, 2009: 24).

Tanzimat dönemiyle birlikte yüzünü Batı'ya dönen Osmanlı aydınları arasında çeviri faaliyetleri de bu dönemde hız kazanmıştı. Öykünülen Bat dünyasından çeşitli eserler çevrilmiştir. Dönemin meşhur paşası Mustafa Reşit Paşa'nın hamiliğinde kurulan Encümen-i Dâniş̧in faaliyetleri, II. Mahmut döneminde eğitim amaçı yurtdışına gönderilenlerin geri dönmesi gibi etmenler Batlılaşmanın diğer sacayaklarını oluşturan unsurlardır.

\section{NAMIK KEMAL (1840-1888)}

"Batı kültürüyle yetişen aydınların Tanzimat devrinde Batı edebiyatını örnek alarak oluşturdukları, 1839-1896 yıllarını kapsayan" Tanzimat edebiyatının en etkili kalemlerinden biri olmanın yanı sıra en popüler isimlerinden biri olan Namık Kemal, "edebiyatımızın yenileşmesinde ve değişmesinde olduğu kadar Tanzimat fikir hayatının oluşmasında ve olgunlaşmasında emeği geçen usta bir kalemdir." (Çalışkan, 2014: 8283)

21 Aralık 1840 tarihinde Tekirdağ'da dünyaya gelmiştir. Ceddi arasında bir kahraman sayılabilecek Topal Osman Paşa bulunmaktadır. Abdülhamit döneminde sarayda müneccimbaşı olarak çalışmış babası Mustafa Asım Bey, Namık Kemal'in kendi ifadeleriyle oldukça zeki bir insandır. Asım Bey, mütedeyyin ama taassuptan uzak bir insandır. Kemal'in zekâsını ve yeniliğe açık genlerini babasına borçlu olduğu söylenebilir. Annesi bir Arnavut olan Kemal henüz iki yaşındayken annesi vefat etmiştir. Bu durum, Kemal'in babasından ayrılıp anneannesi Mahdume Hanım ve dedesi Abdüllatif Paşa ile ikamet etmeye mecbur bırakmıştr. Dokuz yaşına geldiği vakit İstanbul'da basının yanına 
yerleşip eğitim görmeye başlamıştır. İstanbul'da kısa eğitim hayatı sonrası dedesinin tayini dolayısıyla Kars'a gitmiştir. Kars yolculuğu ve sürecinin Namık Kemal'deki 'vatan' fikrinin oluşum sürecinin başlangıç noktası olduğu söylenmektedir. Kemal'in şairlik serüveni de Kars hayatında denk gelir. İlk beytini henüz on iki yaşındayken yazar;

Gelip mektubu mergubun safa bahşeyledi cânâ

Sürûrumdan serim tacı irişti arşı Rahmana

Kars'ta bir yıl kaldıktan sonra dedesinin tekrar tayini çıkar ve bu defa Sofya hayat başlar ki bu dönemin Kemal'in kemali bakımından önemli bir dönemdir. Sofya'da eğitimine devam etmiş bilgi ve görgüsünü arttırmak için çabalamıştır. Sofya'da on alt yaşındayken evlenmiş birkaç ay sonra da dedesi ile birlikte İstanbul'a gelmiştir. Çok geçmeden önce anneannesini sonra da dedesini kaybetmiş ve babasının yanına yerleşmiştir. İstanbul'da o dönem edebî çevreleri eski ve yeni olarak iki grup vardı. Eskilerin arasına girmişti ilkin ve şiirleriyle o grup içerisinde dikkatleri üzerine çekmeyi başarmışt. Encümeni Şuara meclisine girdiği sırada henüz on yedi yaşındaydı. Bu meclisten Eşref Paşa Kemal'e 'Namık' mahlasını vermiştir. Ama bu meclis içerisinde kendisini asıl etkileyen Leskofçalı Galip olmuştur (Bolayır, 1930: 2-18).

Aynı dönemde Tanzimat Fermanı ile birlikte oluşan ortam içinde Kemal yeni fikirlerle tanışmış ve İmparatorluğun Bat'ya açılan en önemli penceresi olan Tercüme Odası'na girmiştir. Tercüme Odası, Osmanlı'nın Batılılaşma yanlısı idarecilerinin ve aydınlarının bir arada bulunduğu ve yetiştiği yer hüviyetindedir. Kemal'in burada Fransızca öğrenmeye başlaması, Fransız İhtilali ve sonrasında oluşan fikri akımları incelemesine imkân vermiştir (Akyılmaz, 1999: 235).

Şinasi, dönemin Batılılaşma hareketinin en öne çıkan ismidir. Namık Kemal'in Şinasi ile tanışması hayatının yüz seksen derece değişip farklı bir mecraya doğru akmasına vesile olmuştur. Şinasi ile birlikte yüzünü Batı'ya dönmüş içindeki inkılapçı vatan aşkı açığa çıkmıştır. Tasvir-i Efkâr gazetesini Şinasi ile birlikte çıkarmaya başlarlar. Bir müddet sonra Şinasi'nin Fransa'ya gitmesiyle Namık Kemal gazeteyi tek başına çıkarır. Şinasi'nin ayrılması Namık Kemal'in içindeki coşkun tarafin hür ve serbest kalıp çağlamasına vesile olmuştur. Bu özgürlük hissiyatyla daha heyecan dolu, daha ateşli yönünü açığa çıkarmıştır (Bolayır, 1930: 18-24).

1865 yılında Şinasi'nin gazeteyi bırakmasını müteakip, Namık Kemal bir yandan gazeteyi tek başına çıkarmaya başlamışken beri yandan İttifak-i Hâkimiyet isimli derneğin kurucuları arasında yer almıştır. Bu dernek gizli bir dernek olma hüviyetinin yanı sıra daha sonradan Yeni Osmanlılar Cemiyeti'ne ('Genç Osmanlılar') dönüşecek olan dernektir. Dernek Tanzimat ile başlayan yenileşme hareketinin devamını talep ederken Abdülaziz'in şahsi iradesine karşı çıkmakta ve devlet idaresinde yeni bir teşkilatlanma talebinde idiler. (Karpat, 2012: 63). Bu fikriyat ile hükümet aleyhinde yazdığı makaleler gazetenin kapatılmasına ve Kemal'in Erzurum'a vali muavini olarak atanmasına sebep olur. Ama Namık Kemal bunun yerine Ziya Paşa ile birlikte Paris'e gider. Burada bir müddet kaldıktan sonra Londra'ya gidip Hürriyet gazetesini çıkarır. 1870'te İstanbul' geri döner.

'ibret' gazetesinde imzasız yazılar kaleme alır. Siyasetten uzak kalmak ve yazı yazmamak kaydıyla affedildiği için doğrudan ismini kullanmaz. Ama hem 'ibret' için hem de 'Hadika' gazetesi için kaleme aldığı yazılar nedeniyle her iki gazete de "adab-ı devlet ü Hükümet'e" aykırı yayın gerekçesi ile kapatılırlar (Aydoğan, 2003: 16). 
1 Nisan 1873'te Gedikpaşa tiyatrosunda oynanan 'Vatan Yahut Silistre' oyunu sonrası olaylar çıkar. Sonrasında Namık Kemal ve dört arkadaşı (Ahmet Mithat, Ebuzziya Tevfik, Hacı Nuri, Bereketzade İsmail Hakkı) yargılanmadan sürgüne gönderilirler (Aydoğan, 2003: 17-18). Namık Kemal'in sürgün yılları oldukça sıkıntılı geçer. Ama Tanpınar'ın da ifadeleriyle asıl olarak kendisini edebiyata verdiği sükûnu bulduğu dönem Magosa yıllarıdır (Tanpınar, 2002: 179).

Sürgün sonrası İstanbul'a döner Kanun-i Esasi'yi oluşturan heyette yer alır. Ama okuduğu;

"Bâde, arak tükendi sâki getir müselles

Eşşey'ü lâ yüsennâ illa ve Kad yüselles"

beytinde ikinci mısraın «bir şey iki defa tekerrür etti mi üçüncü defa da tekerrür eder» (Sungu,1941: 23) manasında olmasını Sultan Abdülhamit'in de kendinden önceki iki sultan gibi tahttan indirileceği imasına yorulmasıyla alt ay hapis cezasına çarptırılır. Sonradan beraat eder etmesine ama kendisi hakkında bu ve buna benzer pek çok jurnalleme faaliyetinde bulunulur (Safi, 2006: 45). Nitekim bu jurnallemeler sonrası Kanun-i Esasi'nin 113. ${ }^{1}$ Maddesinin II. Abdülhamit'e verdiği 'yargısız sürgün' yetkisi ile Namık Kemal ve muhalif pek çok isim sürgüne tabi tutulmuştur (Dizdaroğlu, 1995: 13). Durumun enteresan yanı yasa hazırlanırken bu maddeye destek veren Namık Kemal bu maddenin kurbanları arasında yer almıştır.

Namık Kemal için yeni sürgün yeri Midilli'dir. Burada beş yıl süreyle görev yapmış, burada iken Adalarda yaşayanların sorunları ile ilgili hazırladığı raporla 'Nişan-ı Osmanlı' madalyasıyla ödüllendirilmiştir. Bu çalışmaya konu olan 'Vâveylâ' şiirinin yanı sıra 'Murabba' ve 'Vatan Mersiyesi' şiirlerini de burada kaleme almıştı. Diğer bir deyişle bu yıllar Magosa'dan sonra eser bakımından Namık Kemal'in en verimli dönemidir. Midillide zatürre geçiren Kemal, Rodos'tan Sakız adasına görev yeri değiştirilir. Sakız adasının nemli havası ve Namık Kemal'in ikinci zatürre hadisesi nedeni ile 2 Aralık 1888 yılında yaşamını yitirir (Dizdaroğlu, 1995: 14).

\section{ESER}

"Şiir bizi verir, bazen doğrudan doğruya verir çığlık olur. Fikir halinde verir, hikmet olur" (Tanpınar, 2002: 281). Tanpınar'ın şiire dair bu ifadeleri hem 'Vâveylâ' şiirinin hem de Namık Kemal'in poetikasının özü mahiyetindedir. Namık Kemal'in üslubuna dair söylenebilecek belki en kısa ama hiç şüphesiz en etkili ifadelerden biridir. Kemal'in sözünü budaktan sakınmayan, onu 'doğrudan doğruya' bir çığlık edasıyla sarf ettiği konusunda hem eserlerinde hem de hayatında pek çok iz bulabilmek mümkündür. Hele ki mevzubahis 'vatan' ise bu çığlık, bu 'Vâveylâ' katbekat artarak o gür sedasıyla yankılanmaktadır. Üstelik bu haykırışlar çığlıklar sırf ses ve bağııı̧ değildir, içerisinde 'hikmet' de barındıran bir hüviyettedir.

1 “Madde 113. - Mülkün bir cihetinde ihtilâl zuhur edeceğini müeyyid asar ve emarat görüldüğü halde Hükûmeti seniyenin o mahalle mahsus olmak üzere muvakkaten (idare-i örfiye) ilânına hakkı vardır. (İdare-i örfiye) kavanin ve nizamatı mülkiyenin muvakkaten tatilinden ibaret olup (idare-i örfiye) tahtında bulunan mahallin sureti idaresi nizamı mahsus ile tâyin olunacaktır. Hükûmetin emniyetini ihlâl ettikleri idare-i zabıtanın tahkikatı mevsukası üzerine sabit olanların memâliki mahrusai şaheneden ihraç ve teb'id etmek münhasıran Zat Hazireti Padişahinin yedi iktidarındadır." (http://www.anayasa.gen.tr/1876ke.htm) 
'Vâveylâ' şiiri Namık Kemal'in 'hikmet' dolu 'çığlıklarından' bir diğeridir. Çığlıktır, haykırıştır çünkü mevzu 'vatandır'. 'Vatan' aşkını kuru bir edayla, sessiz bir sedayla anlatmak ise Kemal gibi coşkun ve ateşli üslubuyla namlanmış bir edibe yakışmayacağından o pek bilindik üslubu ile şiirine - ya da daha şiirsel minvalde haykırışına - 'Vâveylâ' ismini uygun görmüştür. Kemal'in zihnindeki 'vatan' kuru bir toprak parçası asla değildir. Bilakis 'o', varlıkların en değerlisi, Tanrı'dan sonraki yeryüzünde insanın varoluşuna aracılık eden, cennetin ayakları altına serildiği en kıymetlimiz olandır, o hayat bahşedici konumda olan kadındır. Kemal için 'vatan' tarifi imgelem düzleminde 'kadın' ile eşdeğerdir. Nitekim 'vatan' anlatımı şiiri boyunca hep bir kadın metaforu üzerine kurguludur.

Vâveylâ
Feminin rengi aks edip tenine
Yeni açmış güle misâl olmuş
İn'itâfiyla bak ne âl olmuş
Serv-i sîmîn safâlı gerdenine
O letâfetle ol nihâl-i revân
Giriyor göz yumunca rü'yâma
Benziyor aynı, kendi hülyâma
Bu tasavvur dokundu sevdâma
Âh böyle gezer mi hiç cânân?
Gül değil arkasında kanlı kefen
Sen misin? Sen misin?! Garîb vatan!

Kemal, dört bölümden oluşan şiirin ilk bölümünü 'vatan' tarifine ayırmıştır. Onun gözünde 'vatan' bir kadın figürü gibidir. Bu sebeple tıpkı bir kadını tasvir eder gibi 'vatanı' tasvir etmektedir. 'Vatan', ağız, ten, boyun gibi fiziksel özellikleri olan ve fidan gibi yürüyen kanlı canlı bir kadın gibidir. Hatta 'rüya' âlemine girebilen ve dahi 'hülyalara' benzeyebilen soyut bir yanı da mevcuttur. Bu noktada düşlediği hülyasından birdenbire uyanıverir şair ve acı gerçeklikle yüzleşiverir; al renginde gül sandığı 'kanlı kefenmiş' meğerse. İnanamaz gözlerine ve tekrar tekrar sorar "Sen misin? Sen misin?! Garib vatan!"

Kemal'in eş'arı içerisinde imgeler daima canlı ve gerçekçidir. Soyut imgeler bile Kemal nezdinde gerçek birer varlığa dönüşebilmektedir. Vatanı kişileştirmesinin akabinde kendisiyle karşılıklı olarak konuşması okuyucunun zihninde meramın canlandırılmasını kolaylaştırmaktadır. Aynı zamanda usta bir tiyatro yazarı olan Namık Kemal'in soyut bir kavramı bile konuşturup, ona can vererek kişileştirme yeteneğini başarıyla sergilemektedir.

Eski üslupla yetişip yeni üslubu sonradan edinmiş Namık Kemal'in "serv-i sîmîn safâlı gerden" mısraı için İsmail Hikmet Ertaylan; " tamamıyla Şarklıdır" der ve ekler: "Kemal'in yazılarında ve bilhassa şiirlerindeki çeşni de sanat da, zihniyet de, heyecan da, hat da hep Şarklıdır" (Ertaylan, 2011: 215-216). Ertaylan'ın bu tespiti Namık Kemal için ileri sürdüğümüz 'düalizm' savını da destekler niteliktedir. 
Bu güzellikte hiç bu çağında

Yakışır mıydı boynuna o kefen?

Cisminin her mesâmı yâre iken

Tuttun evlâdını kucağında.

Sen gidersen bizi kalır sanma

Şühedân oldu mevt ile handân

Sağ kalanlar durur mu hiç giryân

Tende yaştan ziyadedir al kan

Söyleyen söylesin sen aldanma

Sen gidersen bütün helak oluruz

Koynuna cân atar da hâk oluruz

Kemal, şiirin ikinci bölümünde de 'vatanla' hasbihalini sürdürmektedir. Güzelliğinin bu çağında 'kefeni' yakıştırmaz ona, sitem doludur adeta. 'Vatan' bir annedir artı. Üstelik çok da fedakâr bir annedir. Öyle ki her zerresi yara içerisinde olmasına rağmen evladını kucağında tutmaya devam eden şefkatli bir anne. Bu annenin ardında ne gözü yaşlı bir şekilde kalmaya ne de şehitlerin ölümle neşe bulduğu bir ahvalde, henüz tende de yaştan fazla kan var iken geride durup beklemeye asla niyetli değildir şair. İçini ferah tutmasını, söylenenlere adanmamasını salık verir 'annesine'. Çünkü onun gidişi demek yok oluşumuz demektir. Ama bu yok oluş bir firak asla değildir, tam tersine bir vuslat, bir 'hâk' oluş yani toprağa karışıp 'vatanın' bir parçası olup onun koynunda yatmadır.

Kemal, şiirin ilk bölümünde kadın formunda takdim ettiği 'vatan' için ikinci bölümde bir üst perdeye çıkarak 'anne' imgelemini kullanmaktadır. 'Vatanı' bir anlamda sıradanlıktan sıyırıp daha bir kutsiyet atfettiği bir konuma çıkarmıştır. Annedir artık 'vatan'; evladına sahip çıkan onu içinde bulunduğu zor şartlara rağmen kollayıp gözeten. Aynı zamanda uğruna ölümün neşe ile karşılandığı bir olgudur artık. Kuvvetle muhtemeldir ki Kemal, devrin şartları da göz önünde bulundurulursa ülkenin halini fena ve her 'mesâmı yâre' içerisinde bir vaziyette olduğuna işaret etmektedir. Bu durumdan çıkmak için her türlü fedakârlığın yapılması hatta gerekirse ölümün bile göze alınmasının icap ettiğini düşünmektedir.

$$
\begin{aligned}
& \text { Git vatan! Kâ’be'de siyâha bürün } \\
& \text { Bir kolun Ravza-i Nebîıye uzat } \\
& \text { Birini Kerbelâıda Meşhedıe at } \\
& \text { Kâ'inâta o hey'etinle görün! } \\
& \text { O temâşâya Hakk da âşık olur } \\
& \text { Göze bir âlem eyliyor izhâr } \\
& \text { Ki cihândan büyük letâfeti var } \\
& \text { O letâfet olunsa ger inkâr } \\
& \text { Mezhebimce demek muvâfik olur: } \\
& \text { Aç vatan göğsünü Illahıına aç! } \\
& \text { Şühedânı çıar da ortaya saç! }
\end{aligned}
$$

Şairin 'vatan' ile konuşması bu bölümde de devam eder. Bu kez 'Kâ'be'de' siyaha bürünmeye gönderir vatanı. İslam'ın kutsal topraklarına, dinin anavatanına gönderir 'vatanı'. Bir kolunu Peygamberin türbesine diğerini torunu Hz. Hüseyin'in şehitliğine atmasını ister. Bu vaziyette bir 'temâşâya' Hakk'ın da hayran kalacağını belirtir. Bu duruşun barındırdığı güzelliğin inkâr edilemeyeceğini; ola ki böyle bir ihtimal vuku bulursa da koynunda sakladığı şehitleri çıkarıp ortaya saçmasını salık verir. Kemal, şiirin 
bu bölümünde doğrudan pek çok manevi ve kutsal mekânlara yer vermiştir. Yer verdiği bu mekânlar arasında 'Kâ'be, Ravza-i Nebî, Kerbelâ ve Meşhed' kelimeleri ile hem coğrafi hem de manevi vatanın sınırlarını çizmektedir (Şengül, 1999: 195-213). Namık Kemal'in 'vatan' için çizdiği istikamet 'Kâbe'ye' doğrudur. İsmet Özel, 'Kâbe' denince neden vatan anlaşılması gerektiğini şu şekilde açıklar;

"Vatan deyince önce Kâbe'yi hatrlamamızın manasını kavramamı lazım. Neden Kâbe deyince vatan anlaşılır? Bunun kimle, ne alakası vardır? Kâbe, kâinatın merkezinin izdüşümüdür. İlk mektepten itibaren çocuklara dünyanın en yüksek yeri olarak Everest Tepesi'ni öğretirler. Bu yanlıştr. Dünyanın en yüksek yeri Kâbe'dir. Çünkü Kâbe kâinatın merkezinin izdüşümüdür. Yani dünyada her şey Kâbe'nin altındadır. Onun için bizim vatanımız Kâbe'dir" (Özel, 2011).

'Kâbe', tüm Müslümanların kutsal mekânı olmanın yanı sıra sembolik olarak Müslümanların anavatanı olma hüviyetini de taşımaktadır. Her ne kadar yüzü Batıya dönük bir Tanzimat aydını da olsa Namık Kemal'in kutsal İslami mekânlara doğru bir istikamet çizmesi içindeki Müslüman kimliğin zuhur etmesi olarak okunabilir. 'Vatan' için çizdiği rota Doğuya doğrudur, Batiya değil. Bu durumu, Kemal 'in kararsız ve düalist yönünün bir diğer işareti olarak görmek mümkündür.

De ki Yâ Rab! Bu Hüseynıindir
Şu mübârek Habîb-i Zî-şân'ın
Şu kefensiz yatan şehîdânın
Kimi Bedr'in kimi Huneynıindir
Tazelensin mi kanlı yâreleri?
Mey dökülsün mü kabr-i Ashâb’a?
Yakışır mı sanem bu mihrâba?
Haç mı konsun bedel şu mîzâba?
Dîninin kalmasın mı bir eseri?
Âdem evlâdı birtakım câni
Senden alsın mı sâr-i şeytânî?

Bir önceki bölümde kullandığı dini terimleri bu bölümde de kullanmaya devam eder şair. 'Vatanı' doğrudan Tanrı ile muhatap kılar. Hz. Hüseyin'i gösterir bir tarafta, 'Habîb-i Zişan' Peygamber vardır öte tarafta, Bedir ve Huneyn şehitleri de öbür yandadır. Feryat figan halde başlar sorgulamaya; kanlı yaraları tekrar mı tazelensin, şarap mı dökülsün ashabın kabrine, mihrap bir puta mı reva olsun? Ya da haç mı konsun mîzâba, dinden geri hiçbir eser kalmasın mı veyahut birtakım cani güruh şeytanın öcünü mü alsın senden? Kemal, şiirin şimdiye dek olan bölümlerinde soyut bir kavram olarak 'vatanı' kişileştirmiş ve onunla karşılıklı bir diyalog içerisindeymiş gibi konuşmuştu. Bu bölümde ise 'vatanın' karşısına Tanrı'yı koyarak hitabı doğrudan Tanrı'ya yöneltmektedir. Ve bu konuşmanın cereyan ettiği esnada Bedir ve Huneyn savaşlarından bahseder. Bedr'in ve Huneyn'in adının anılması işaret ettiği manalar bakımından önemlidir. Özel'in ifadeleri ile bu iki savaş bizim dünyada insan olarak haysiyet sahibi olmamızı sağlayan iki gazâdır. Bedir savaşı, bu haysiyeti ele geçirmek için, Huneyn savaşı ise bu haysiyeti kaybetmemek için giriştiğimiz iki muharebedir (Özel, 2011). İslamiyet tarihi açısından bu iki savaştan biri varlık mücadelesinin (Bedir), bir diğeri ise varlığını sürdürme (Huneyn) mücadelesinin önemli iki savaşıdır. Namık Kemal, bu bölümde ileri sürdüğü yedi soru ile adeta varlık- 
yokluk halinde yaşanabilecek en kötü senaryoyu gözler önüne sunma kaygısı taşımaktadır. 'Vatan'ın düşmesini tek başına bir toprak yitimi olarak görmediği aşikârdır. Bu düşüşün tüm dini ve manevi değerleri ve dahi kutsal adına ne varsa beraberinde götüreceğini işaret etmektedir. Kaybın boyutlarını tüm çıplaklığı ile gözler önüne sermektedir. Hatta daha da ileri giderek kalubeladan beri var olagelmiş bir 'sâr' mevzuun da bahsini açar. Tanrı'ya seslenerek şeytanın öcünü almasına izin mi vereceksin diye bir sorgulama içerisine girer. Özel, 'sâr' terimi ile ilgili olarak şu düşünceleri ileri sürer. 'Sâr' terimi burada bilinçli bir kullanımdır. 'Intikam' kelimesi kullanımaz. Vahşice saldırma, rakibini yok etme anlamındaki 'sâr' kelimesi tercih edilir. 'Intikam' - Allah'ın adlarından birisi Müntekim'dir - bir hakka istinaden alınır. İntikam almak içerisinde hak barındııı, yani haklının yapacağı eylemdir. Oysaki burada hakkı olmayanların vatandan aldıkları şeytânî bir iştir. Bir saldırı, şeytânî bir saldırıdır (Özel, 2011). Kemal, bu ifadelerle bir manada feveran içerisinde Tanrı'ya yakararak 'vatana' sahip çıkması 'Vâveylâ' koparmaktadır.

\section{SONUÇ}

Namık Kemal, Tanzimat edebiyat zümresi içinde nevi şahsına münhasır bir kalem olarak öne çıkmaktadır. Onu, çağdaşlarından farklı kılan pek çok özellik mevcuttur. Türk toplumu ve milleti üzerinde eşine az rastlanır özellikte bir etkisi bulunmaktadır. Yeni ve farklı bir değişim olarak algılanabilecek 'Türk Edebiyat Tarihi ve Türkiye'de Batlılaşma' dönüşümüne hem ön ayak olmuş hem de devrine damga vurmuş bir isimdir. Şinasi'nin başlangıcını yaptığı yeniliklerin sağlam temeller üzerine oturmasını sağlayabilmiştir. Bu yeniliklerin yerleşmesi sürecinde hem siyasi hem de edebî anlamda yetiştiği kültürü reddetmemiş, aksine bagajındaki ilim ve irfanı bu yeni hareketin oluşum sürecinde kullanmıştır.

Eserlerinde karşımıza sıkça çıkan düalizm/ikilik işaretlerinin temel nedenini 'içinde büyüdüğü kültür' ve 'yüzünü döndüğü kültür' arasındaki gidip gelmeler olarak göstermek mümkündür. Bu düalizm, Namık Kemal'de bir tutarsızlık algısına sebep olmuş gibi görünse de bir kararsızlık belirtisi olması daha muhtemeldir. Ama daha doğrusu bu durumu yeni bir hareketin, neslin, edebiyatın ve dahi milletin doğum sancıları olarak okumak da mümkündür. Namık Kemal, hem burada incelediğimiz şiirinde hem de diğer eserlerinde en büyük ülküsünün 'hürriyet ve vatan aşkı' olduğunu apaçık bir edayla okuyucuya göstermektedir. Hatta göstermekle kalmayıp feryat figan bir halde bunu haykırmaktadır. Haykırış, coşku, heyecan ve bağırış Kemal'in en belirgin ve kendine has üslubudur. 'Vâveylâ' şiirini de bu üslupla ele almıştır.

Bu incelme vasıtasıyla ulaştı̆ımız en mühim netice Namık Kemal'in tüm zerrelerinde hissettiği 'vatan aşkına' bizatihi şahitlik etmek olmuştur. Nitekim oğlu Ali Ekrem Bolayır'ın da belirttiği üzere "'Vâveylâ' Abdülhak Hamit te dâhil olduğu halde hiçbir şairimizin yazamadığı derecelerde yüksek vatan şiiri” (Bolayır, 1930: 28) olarak öne çıkar. Ülkenin içinde bulunduğu şartların fenalığı ile dertlenen ve bu dertlere deva adına elinde kalemi dışında bir aracı bulunmayan 'vatan aşı̆̆ı' Namık Kemal, bu aracı en etkili biçimde kullanmıştr. Bu etki, kendi nesli ve kuşağı üzerinde, kendinden sonraki nesiller üzerinde ve hatta günümüz nesilleri üzerinde dahi kalabilmiş bir etkidir. Kemal'in mirası sadece edebî eserleri değildir, aynı zamanda milletinin damarlarına aşıladığı 'hürriyet ve vatan aşkı' şuurudur.

Çok uzaklardan, bir asrın üzerinde bir zamandan evvel okura 'Vâveylâsı' ile seslenen 'vatan şairi' Namık Kemal'in çığlığını günümüz edebiyat dünyasında bile duyabilmemiz şairin ne derin bir etkisi olduğunu idrak etmek için kâfidir kanaatimizce. 


\section{International Journal of Social Sciences}

\section{KAYNAKÇA}

Adoğan, B. (2003). Namık Kemal'in Magosa Sürgünlüğü . Hapishaneler Sempozyumu. İstanbul: Marmara Üniversitesi Türkiyat Araştırma ve Uygulama Merkezi.

Akyılmaz, G. (1999). Birinci Jön Türk Hareketinin (Yeni Osmanlılar Cemiyeti) İdeolojisine Bir Örnek: 'Namık Keml ve ikirleri'. Selçuk Üniversitesi Sosyal Bilimler Meslek Yüksek Okulu Dergisi, Sayı:2.

Bolayır, A. E. (1930). Namık Kemal. İstanbul: İstanbul Devlet Matbaası Yayınları.

Çalışkan, A. (2014). Namık Kemal'in Hürriyet Kasidesi ve Tahlili. Uluslararası Sosyal Araştırmalar Dergisi, Cilt:7, Sayı:31.

Dizdaroğlu, H. (1995). Namık Kemal. İstanbul: Varlık Yayınları.

Ertaylan, I. H. (2011). Trük Edebiyat Tarihi I-IV. Ankara: Türk Tarih Kurumu Yayınları.

Gariper, C. (2007). Yeni Türk Edebiyatı El Kitabı. Ankara: Grafiker Yayıncılık.

Gözler, K. (1999). Türk Anayasaları. Bursa: Ekin Kitabevi Yayınları (http://www.anayasa.gen.tr/1876ke. htm).

Kaplan, M. (1991). Türk Edebiyat Üzerine Araştırmalar 3 Tip Talilleri . İstanbul: Dergah Yayınları.

Kaplan, M. (2015). Şiir Tahlilleri 1 Tanzimattan Cumhuriyete Kadar. İstanbul: Dergah Yayınları.

Karpat, K. H. (2015). Kısa Türkiye Tarihi 1800-2012. İstanbul: Timaş Yayınları.

Korkmaz, R. (2007). Yeni Türk Edebiyati El Kitabı. Ankara: Grafiker Yayıncılık.

Moran, B. (2009). Türk Romanına Eleştirel Bir Bakış 1. İstanbul: İletişim Yayınları.

Özel, İ. İstiklal Marşı Derneği. 15.10. 2015 tarihinde İstiklal Marşı Derneği Web Sitesi: http://www. istiklalmarsidernegi.org.tr/Yazi.aspx?YID=594\&KID=6 adresinden alındı

Roux, J.-P. (2015). Türklerin Tarihi Pasiikten Akdeniz'e 2000 Yıl. İstanbul: Kabalcı Yayınevi.

Safi, İ. (2006). Namık Kemal Hakkında Saraya Verilmiş Üç Jurnal. Celal Bayar Üniversitesi Sosyal Bilimler Dergisi, Cilt:, Sayı:2.

Sungu, i. (1941). Namık Kemal. İstanbul: CHP Ankara Halkevi Yayınları.

Şengül, A. (1992). Yeni Kavramlar Etrafinda Yeni İnsan ve Namık Kemal. Afyon Kocatepe Ünievrsitesi Sosyal Bilimler Dergisi, Cilt:1, Sayı:2.

Tanpınar, A. H. (1992). Edebiyat Üzerine Makaleler. İstanbul: Dergah Yayınları.

Tanpınar, A. H. (2002). Edebiyat Dersleri. İstanbul: Yapı Kredi Yayınları.

Tanpınar, A. H. (2013). On Dokuzuncu Asır Türk Edebiyatı Tarihi. İstanbul: Dergah Yayınları. 